\title{
Coastline change analysis and erosion prediction using satellite images
}

\author{
Putu Aryastana $^{1 *}$, I Made Ardantha ${ }^{1}$, and Kadek Windy Candrayana ${ }^{2}$ \\ ${ }^{1}$ Universitas Warmadewa, Department of Civil Engineering, Denpasar-Bali, Indonesia \\ ${ }^{2}$ Udayana University, Master Student Department of Civil Engineering, J1. PB Sudirman, Denpasar, Indonesia
}

\begin{abstract}
The study of monitoring and analysis of coastline change and erosion prediction has been widely used satellite imagery. Satellite data that is often used in monitoring studies and analysis of coastline changes are Landsat, Quickbird, Allos, SPOT, IKONOS, etc. The aim of study is to determine an average of coastline change and average of coastal erosion in coastal area of Tabanan Regency, Bali Province, Indonesia by using two kind satellite are SPOT 5 in 2009 has a spatial resolution of $10 \mathrm{~m}$ (multispectral) and SPOT 6/7 in 2015 has a spatial resolution $1.5 \mathrm{~m}$. This research contributes to local government and central government as a database in decision making for coastal area management. The result of analysis shows the average of coastline change in Tabanan regency is $13.96 \mathrm{~m}$ and the average rate of coastal erosion is $1.99 \mathrm{~m} /$ year. The coastline movement or erosion has caused the morphological changes.
\end{abstract}

\section{Introduction}

Shoreline change analysis and prediction are important for integrated coastal zone management, and are conventionally performed by field and aerial surveys [1]. Coastline mapping can be defined by direct field measurement, aerial photography analysis and remote sensing analysis by using satellite imagery [2]. Technological developments have led to the use of satellite imagery in coastline change analysis [3].

Satellite data were utilized for coastline change analysis and erosion prediction in many researches. For example IRS satellite data were used to calculate the shoreline change rates, coastal erosion and accreation in southern coastal Tamil Nadu of India[4]. Multitemporal remote sensing data of Landsat MSS and TM from 1976 to 2000 , totaling twenty scenes, were used to examine the changing pattern of accretion and erosion of the modern Yellow River subaerial delta with GIS tools [5]. Digital Orthophoto Quarter Quadrangles (DOQQs) and black and white aerial photographs were used to calculate shoreline change rate in Neuse River Estuary, USA [6].

Landsat MSS image of 1979, Landsat TM and ETM+images of 1990 and 2000, SPOT image of 2003 and the topographic map 1:100,000 of 1966 and a nautical map scale 1:150,000 of 2003 were utilized to analysis coastline change detection of the Pearl River Estuary, China [7]. Landsat MMS, Landsat TM and SPOT-4 were utilised to estimate the spatio-temporal changes that occurred in the coastal zone between Damietta Nile branch and Port-Said between 1973 and 2007 [8].
Landsat imagery between 2000 and 2014 were utilized to evaluate of annual mean shoreline position at El Saler Valencia, Spain [9]. Combination aerial photographs and sattelite imagery (IKONOS, Quickbird, Worldview2 and Geoeye-1) were used to interpreted shoreline change at Wotje Atoll, Marshall Islands [10]. SPOT image was used to evaluate shoreline in Progreso, Yucatán, México [11]. SPOT 5 and SPOT 6/7 were used to analysis the averege of coastline changes from 2009 and 2015 at Buleleng Regency, Bali Province, Indonesia [3].

The objective of this research is to analysis the average of coastline changes and average rate of coastal erosion in Tabanan Regency based on SPOT 5 and SPOT 6/7 image.

\section{Methods}

\subsection{Satellite data}

Satellite imagery was utilized are SPOT 5 image in 2009 has a spatial resolution of $10 \mathrm{~m}$ (multispectral) and SPOT 6/7 image in 2015 with resolution up to $1.5 \mathrm{~m}$.

\subsection{Study location}

The research sites were conducted along the coast in Tabanan Regency, Bali Province, Indonesia (Figure. 1). Geographical boundary of coast is $\mathrm{X}=270517.1308, \mathrm{Y}$ $=9063446.9826$ to $\mathrm{X}=290829.5643, \mathrm{Y}=$ 9044732.1720 .

\footnotetext{
* Corresponding author: aryastanaputu@yahoo.com
} 


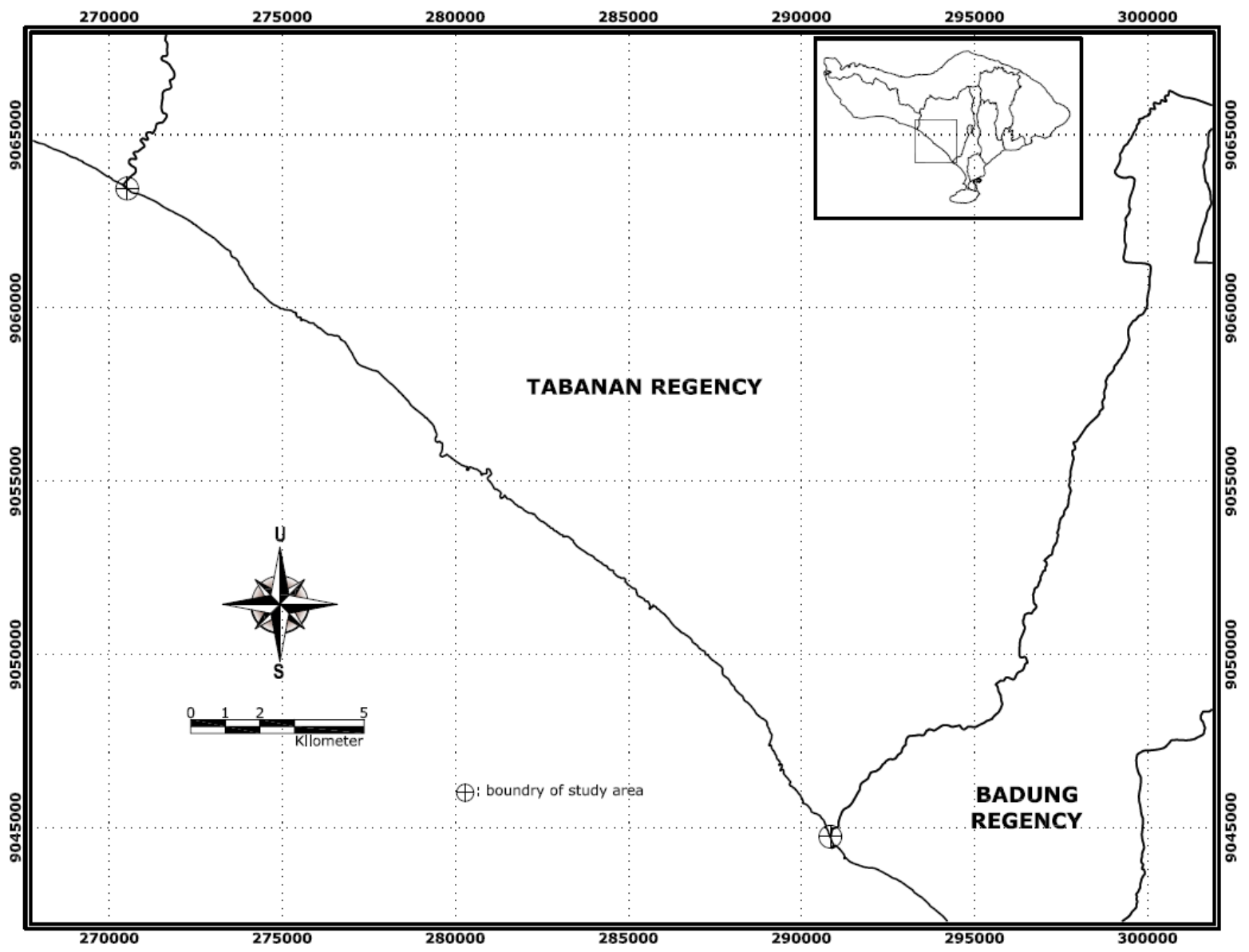

Fig. 1. Area of Study.

\subsection{Image processing}

Image processing consists of image cropping, radiometric correction, geometric correction, band combination and coastline digitization (Fig. 2).

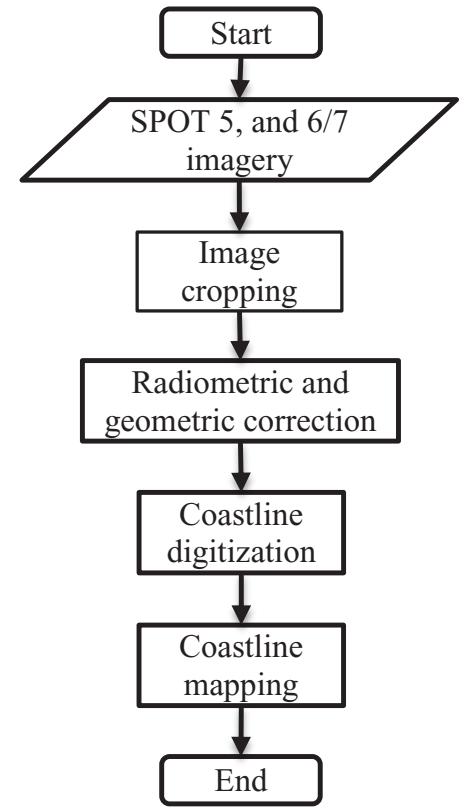

Fig. 2. Flowchart of Image Processing.

\footnotetext{
* Corresponding author: aryastanaputu@yahoo.com
}

\subsection{Waterline correction}

The waterlines were shifted to the tidal datum-based shoreline position based on the equiangular triangle theory. The shifting process and the bottom slope calculation were carried out by sectional calculation [12] The shifted distance, $Y$, was estimated by equation [3]:

$$
Y=\left(T_{k}-\left(\frac{T_{k}}{T_{k}} \times T_{x}\right) \times \operatorname{Tan} \emptyset\right)
$$

Where:

$$
\begin{array}{ll}
Y & : \text { the shifted distance } \\
T_{k} & : \text { sectional HWL (High Water Level) } \\
T_{b} & : \text { Benoa Harbor HWL } \\
T_{x} & : \text { tidal datum where the image was acquired } \\
\text { TanØ } & : \text { coastal slope }
\end{array}
$$

The sectional of coastal slope in Tabanan Regency can be seen in Fig. 3. The tidal datum was utilized to analysis the waterline shifting process is from Benoa harbor and when satellite was acquired time and the shifted distance for each section can be seen on Table 1 . The coastline map of 2009 and 2015 can be seen on Fig. 4. 


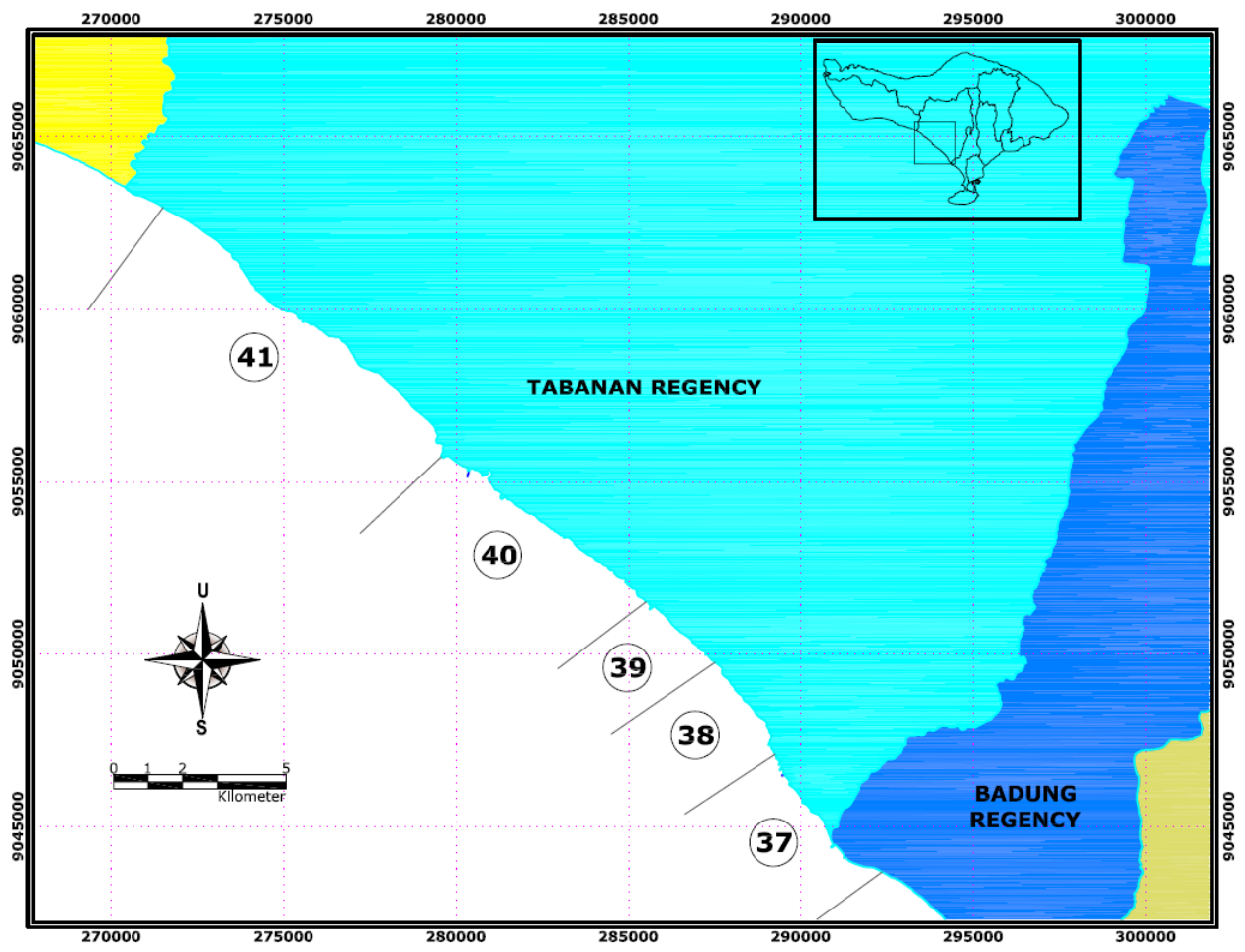

Fig. 3. Sectional of Coastal Slope.

Table 1. The Shifted Distance for Satellite Imagery of 2009 and 2015.

\begin{tabular}{|c|c|c|c|c|c|c|c|}
\hline \multirow{2}{*}{ Section } & \multirow{2}{*}{ Slope } & \multirow{2}{*}{$\mathbf{T}_{\mathbf{k}}(\mathbf{m})$} & \multirow{2}{*}{$\mathbf{T}_{\mathbf{b}}(\mathbf{m})$} & \multicolumn{2}{|c|}{$\mathbf{T}_{\mathbf{x}}(\mathbf{m})$} & \multicolumn{2}{|c|}{$\mathbf{Y}(\mathbf{m})$} \\
\cline { 5 - 8 } & & & $\mathbf{2 0 0 9}$ & $\mathbf{2 0 1 5}$ & $\mathbf{2 0 0 9}$ & $\mathbf{2 0 1 5}$ \\
\hline 37 & 20 & 2.6 & 2.6 & 1.9 & 1.0 & 14.00 & 32.00 \\
\hline 38 & 23 & 2.6 & 2.6 & 1.9 & 1.0 & 18.20 & 41.60 \\
\hline 39 & 18 & 2.6 & 2.6 & 1.9 & 1.0 & 19.60 & 44.80 \\
\hline 40 & 27 & 2.6 & 2.6 & 1.9 & 1.0 & 14.00 & 32.00 \\
\hline 41 & 20 & 2.6 & 2.6 & 1.9 & 1.0 & 10.50 & 24.00 \\
\hline
\end{tabular}

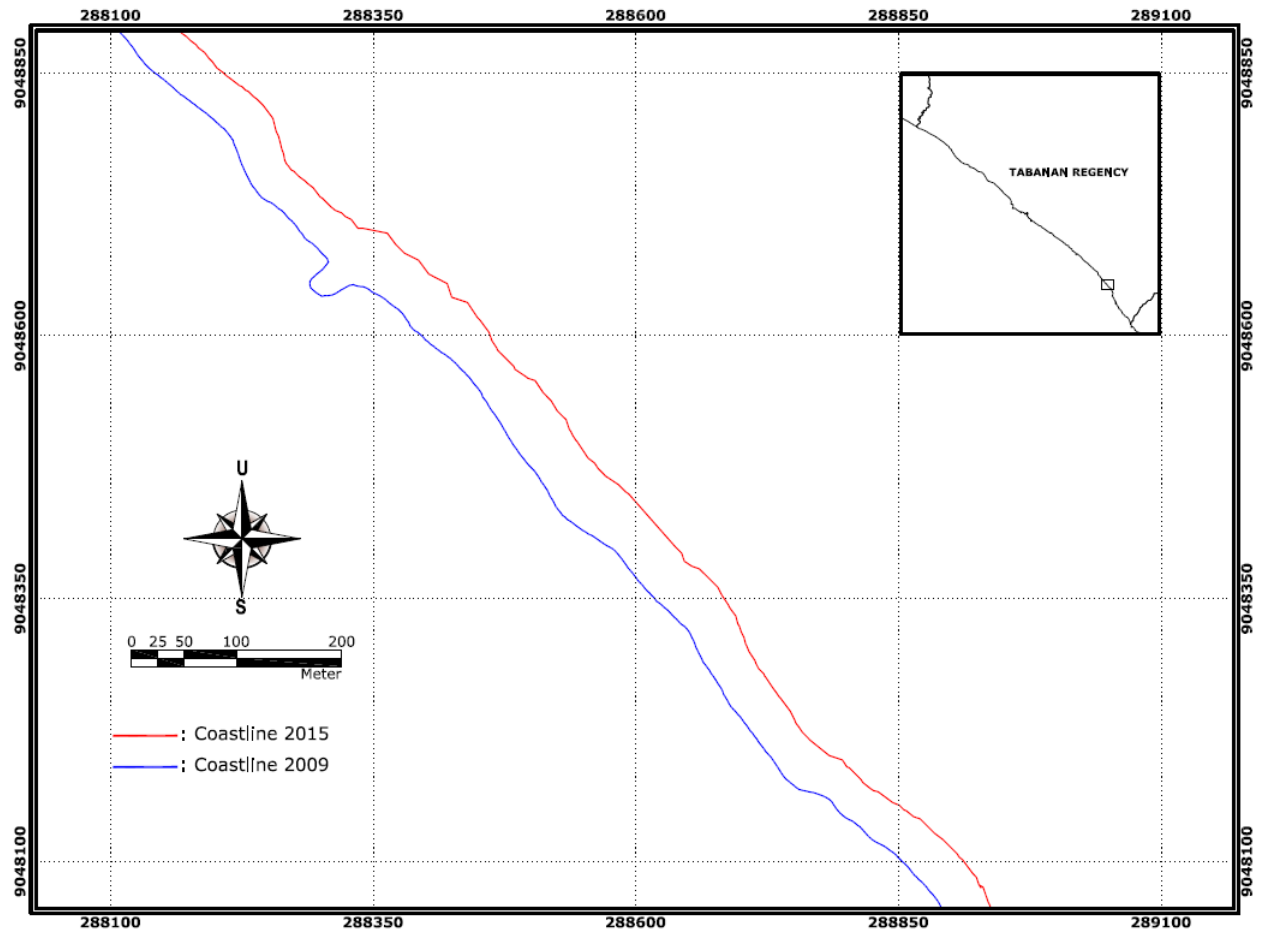

Fig. 3. Coastline Map of 2009 and 2015.

\footnotetext{
* Corresponding author: aryastanaputu $@$ yahoo.com
} 


\subsection{Coastline change and erosion analysis}

Coastline change analysis was calculated based on overlapping method from 2009 and 2015 (Fig. 5). Based on Figure. 5, the length of coastline changes is indicated by A, B, C, D and E. The average of coastline changes (CR) in one area of coastal was estimated by:

$$
\mathrm{CR}=(\mathrm{A}+\mathrm{B}+\mathrm{C}+\mathrm{D}+\mathrm{E}) / 5
$$

Coastal erosion (CE) was calculate based on the average of coastline change divide by total years data:

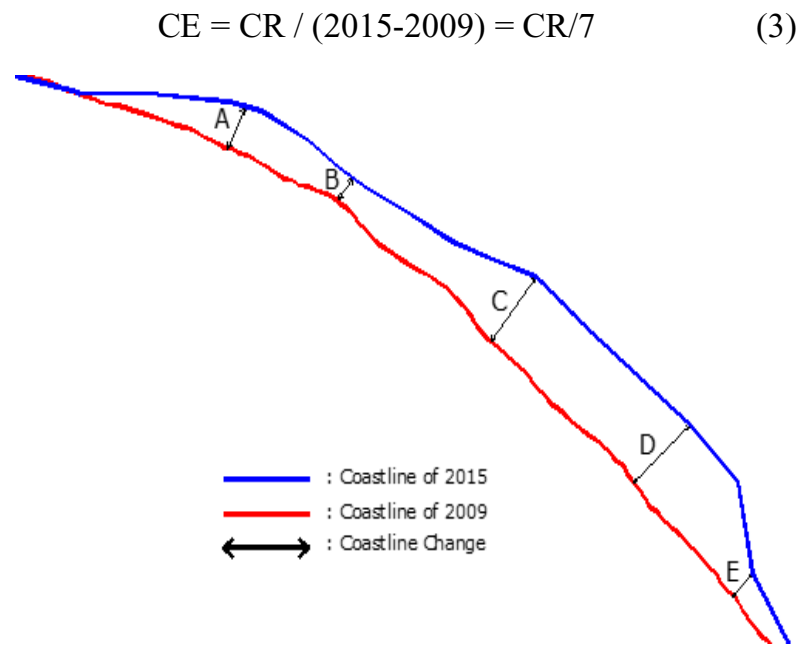

Fig. 4. Coastline Changes Analysis Method [3].

\section{Results and discussion}

The average of coastline change and the average rate of coastal erosion in each area can be seen on Table 2 .

Table 2. Coastline Change and rate of coastal erosion in Tabanan Regency.

\begin{tabular}{|c|l|c|c|}
\hline No & \multicolumn{1}{|c|}{ Coastal Area } & $\begin{array}{c}\text { Coastline } \\
\text { Changes }(\mathbf{m})\end{array}$ & $\begin{array}{c}\text { The Rate Of } \\
\text { Erosion }(\mathbf{m} / \text { year) }\end{array}$ \\
\hline 1 & Nyanyi-Tanah Lot & 12.94 & 1.85 \\
\hline 2 & Kedungu & 11.52 & 1.65 \\
\hline 3 & Pangkung Tibah & 6.61 & 0.94 \\
\hline 4 & Yeh Gangga & 11.09 & 1.58 \\
\hline 5 & Kelating & 11.41 & 1.63 \\
\hline 6 & Pasut & 18.58 & 2.65 \\
\hline 7 & Beraban & 18.14 & 2.59 \\
\hline 8 & Tegal Mengkeb & 11.86 & 1.69 \\
\hline 9 & Berembeng & 10.68 & 1.53 \\
\hline 10 & Soka & 16.26 & 2.32 \\
\hline 11 & Lalanglinggah & 19.32 & 2.76 \\
\hline 12 & Selabih & 19.12 & 2.73 \\
\hline \multicolumn{2}{|c|}{ Average } & $\mathbf{1 3 . 9 6}$ & $\mathbf{1 . 9 9}$ \\
\hline
\end{tabular}

The average coastline change in Tabanan Regency based on SPOT satellite imagery in 2009 and 2015 are $13.96 \mathrm{~m}$ (Table 2). The highest coastline changes occur in Lalanglinggah coastal area which is $19.32 \mathrm{~m}$, while the smallest change occurred in Pangkung Tibah coastal area which is $6.61 \mathrm{~m}$. The average rate of coastal erosion in Tabanan Regency based on SPOT satellite imagery in 2009 and 2015 are $1.99 \mathrm{~m} /$ year (Table 2). The highest of coastal erosion occur in Lalanglinggah coastal area which is $2.76 \mathrm{~m} /$ year, while the smallest coastal erosion occurred in Pangkung Tibah coastal area which is 0.94 $\mathrm{m} /$ year.

The results of this study demonstrate that coastal movement (erosion) has caused coastline changes at the Tabanan Regency. In Tabanan Regency there is no scientific research on coastal inventory, coastline change analysis and the rate of erosion that includes all coasts of Tabanan Regency.

Remote sensing is the best way to reduce the cost of labor and time to develop the assessments of in which some cases are difficult to measure. Besides, satellite imageries are relatively cheap or freely available. These imageries have frequently used to detect deformation analysis. Landsat imagery can be used to detect coastline deformation, but in the low spatial resolution images the shoreline change is difficult to be identified [13].

SPOT image of 2003 have been done to detect the changes of coastlines in Pearl River Estuary, China combines with multi-temporal Landsat images, topographical and nautical data [7].

\section{Conclusions}

The average coastline change in Tabanan Regency based on SPOT satellite imagery in 2009 and 2015 are $13.96 \mathrm{~m}$ The average rate of coastal erosion in Tabanan Regency based on SPOT satellite imagery in 2009 and 2015 are $1.99 \mathrm{~m} /$ year. The result indicated erosion has been done in Tabanan regency from 2009 to 2015 caused by morphological changes.

The author would like to thank RISTEK DIKTI for support the research grant. Also thank to Balai Wilayah Sungai Bali Penida and Department of Public Work Tabanan Regency for supporting satellite data, name of coastal area.

\section{References}

1. Maiti S, Bhattacharya AK. Shoreline change analysis and its application to prediction: A remote sensing and statistics based approach. Mar Geol 257 (1-4):11-23. (2009)

2. Guariglia A, Buonamassa A, Losurdo A, Saladino $\mathrm{R}$, Trivigno ML, Zaccagnino A, A multisource approach for coastline mapping and identification of shoreline changes. Ann Geophys. 49(1):295304. (2006)

3. Aryastana P, Ardantha IM, Nugraha AE, Candrayana KW. Coastline Changes Analysis in Buleleng Regency by using Satellite Data. In: The 1st Warmadewa University International Conference on Architecture and Civil Engineering. p. 106-13. (Warmadewa Press, Denpasar, 2017)

Corresponding author: aryastanaputu@yahoo.com 
4. Sheik Mujabar P, Chandrasekar N. Coastal erosion hazard and vulnerability assessment for southern coastal Tamil Nadu of India by using remote sensing and GIS. Nat Hazards. 69(3):1295-314. (2013)

5. Chu ZX, Sun XG, Zhai SK, Xu KH. Changing pattern of accretion/erosion of the modern Yellow River (Huanghe) subaerial delta, China: Based on remote sensing images. Mar Geol. 227(1-2):13-30 (2006)

6. Cowart L, Reide Corbett D, Walsh JP. Shoreline change along sheltered coastlines: Insights from the neuse river estuary, NC, USA. Remote Sens. 3(7):1516-34 (2011)

7. Li X, Damen MCJ. Coastline change detection with satellite remote sensing for environmental management of the Pearl River Estuary, China. J Mar Syst 82(SUPPL.):S54-61 (2010)

8. El-Asmar HM, Hereher ME. Change detection of the coastal zone east of the Nile Delta using remote sensing. Environ Earth Sci. 62(4):769-77 (2011)

9. Almonacid-Caballer J, Sánchez-García E, PardoPascual JE, Balaguer-Beser AA, Palomar-Vázquez J. Evaluation of annual mean shoreline position deduced from Landsat imagery as a mid-term coastal evolution indicator. Mar Geol 372: 79-88 (2016)

10. Ford M. Shoreline changes interpreted from multitemporal aerial photographs and high resolution satellite images: Wotje Atoll, Marshall Islands. Remote Sens Environ 135:130-40, (2013)

11. García-Rubio G, Huntley D, Russell P. Evaluating shoreline identification using optical satellite images. Mar Geol. 359: 96-105, (2015)

12. Liu Y, Huang H, Qiu Z, Fan J. Detecting coastline change from satellite images based on beach slope estimation in a tidal flat. Int $\mathbf{J}$ Appl Earth Obs Geoinf 23 (1): 165-76. (2013)

13. Sabuncu A, Dogru A, Ozener H, Turgut B. Detection of coastline deformation using remote sensing and geodetic surveys. In: The International Archives of the Photogrammetry, Remote Sensing and Spatial Information Sciences - ISPRS Archives. Prague p. 1169-74 (2016) 